\title{
A N-propionylsulfonamide prodrug of K-5a2 provided improved aqueous solubility and hERG inhibition
}

\section{Xiaofang Zuo}

Shandong University

\section{Zhipeng Huo}

Shandong University

Dongwei Kang

Shandong University

Tong Zhao

Shandong University

\section{Erik De Clercq}

K.U. Leuven

\section{Christophe Pannecouque}

Katholieke Universiteit Leuven

\section{Chin Ho Chen}

Duke University

Kuo-Hsiung Lee

University of North Carolina at Chapel Hill Libraries

\section{Xinyong Liu}

Shandong University

Peng Zhan ( $\square$ zhanpeng1982@sdu.edu.cn )

https://orcid.org/0000-0002-9675-6026

\section{Research article}

Keywords: HIV, prodrug, physicochemical properties, aqueous solubility, hERG inhibition

Posted Date: May 13th, 2020

DOI: https://doi.org/10.21203/rs.3.rs-20505/v1

License: (1) (1) This work is licensed under a Creative Commons Attribution 4.0 International License.

Read Full License 


\section{Abstract}

Background Having the potential disadvantages and safety risk of the use of anti-HIV-1 drug candidate K$5 \mathrm{a} 2$ in the longterm treatment of HIV patients in mind, we set out with the goal of finding a secondgeneration backup compound of K-5a2 with the appropriate anti-HIV potency, significantly reduced hERG activity, decreased induction of the CYP enzyme, and improved aqueous solubility. Herein, using a Npropionylsulfonamide prodrug strategy, we report the discovery of compound HM-1

Methods In vitro assay of anti-HIV activities in TZM-bl and MT-4 cells, metabolic stability in HLM and human plasma, measurements of water solubility and Log P, assay procedures for hERG activity, acute and subacute toxicity experiment and cytochrome P450 inhibition assay were carried out for HM-1.

Results HM-1 can be rapidly hydrolyzed to parent drug K-5a2 and exhibited high potency against HIV$1_{\mathrm{NL4}-3}$ strain $\left(\mathrm{EC}_{50}=7.99 \mathrm{nM}\right)$ in TZM-bl cells, $\mathrm{HIV}-1_{\mathrm{IIIB}}$ strain $\left(\mathrm{EC}_{50}=2.9 \mathrm{nM}\right)$ and HIV-1 ${ }_{\mathrm{Y} 181 \mathrm{C}}$ strain $\left(\mathrm{EC}_{50}\right.$ $=5.5 \mathrm{nM}$ ) in MT-4 cells. And it also showed $\mathrm{a}>70$-fold improvement in aqueous solubility and presented a low acute toxicity in mice $\left(\mathrm{LD}_{50}>2 \mathrm{~g} \cdot \mathrm{kg}^{-1}\right)$; no obvious organ damage was detected in the assessment of subacute toxicity. Meanwhile, HM-1 also showed 50 times lower hERG inhibition $\left(\mathrm{IC}_{50}=6.39 \mu \mathrm{M}\right)$ than $\mathrm{K}$ $5 \mathrm{a} 2\left(\mathrm{IC}_{50}=0.13 \mu \mathrm{M}\right)$.

Conclusions It was HM-1 appeared to be free of most of the drawbacks associated with $\mathrm{K}-5 \mathrm{a} 2$ and has been selected for further development as an oral anti-HIV-infection agent.

\section{Background}

Non-nucleoside reverse transcriptase inhibitors (NNRTIs), which target the binding pocket of reverse transcriptase (RT), are a vital component of highly active antiretroviral therapy (HAART) regimens for the treatment of human immunodeficiency virus type 1 (HIV-1) infection, ${ }^{[1-3]}$ due to their potent antiviral activity, high selectivity, modest toxicity, and favorable pharmacokinetics. ${ }^{[4]}$

$\mathrm{K}-5 \mathrm{a} 2$, a promising anti-HIV-1 drug candidate, was recently discovered by structure-based design in our lab. Compared to etravirine (ETR), it is gratifying that $\mathrm{K}-5 \mathrm{a} 2$ was 2.8 fold more potent against HIV-1 wildtype (WT) strain, and 5-fold more potent against single mutants Y188L, E138K and double mutant F227L + V106A, and almost equipotent against L100I, K103N, and Y181C, which justifies its further development as a potential clinical candidate for the treatment of HIV-1 infection (Fig. 1). ${ }^{[5]}$

Despite these encouraging results, further development of K-5a2 faces many challenges for its low aqueous solubility $(<1 \mu \mathrm{g} / \mathrm{mL})$, which is one of the important parameters to achieve a desired drug concentration in systemic circulation to achieve the intended pharmacological response.$^{[5-7]}$ In addition, high hERG liability $\left(\mathrm{IC}_{50}=0.13 \mu \mathrm{M}\right)$ is an important problem encountered with $\mathrm{K}-5 \mathrm{a} 2$, which may engender the potential risk for cardiotoxicity. Hence, challenges associated with poor aqueous solubility and high hERG inhibition to K-5a2, highlight the need for continuous research and development of rational 
chemical modification. The application of the prodrug approach proved to be a successful strategy for improving aqueous solubility and other drug-like profiles of the parental drugs result in a positive impact on their biological efficacy. ${ }^{[8]}$

Recent studies demonstrated that prodrug modification to improve water solubility of some parent drug containing sulfonamide group has been successfully achieved using $\mathrm{N}$-propionyl moiety. ${ }^{[9-11]}$ For example, as a potent NNRTI, GW678248 was limited into clinical trials due to its poor water solubility $(0.18 \mu \mathrm{g} / \mathrm{ml})$. With the aim to improve solubility, N-propionyl sulfonamide prodrug of GW678248 was discovered. GW695634 obviously enhanced aqueous solubility $(92 \mathrm{mg} / \mathrm{ml})$. And the oral bioavailability of GW695634 in rats and dogs (>40\%) was also increased. ${ }^{[12]}$ Besides, the marketed parecoxib was also the N-propionyl sulfonamide prodrug of valdecoxib which is relatively insoluble in water at about $10 \mu \mathrm{g} / \mathrm{mL} .{ }^{[13]}$ Elsulfavirine, a new generation NNRTI, is the prodrug of the active compound VM $1500 \mathrm{~A}$ that obtained its first market authorization in Russia (Fig. 2). ${ }^{[14]}$

Herein, inspired by these recent successful examples, with the aim to enhance aqueous solubility and drug-like profiles of our drug candidate $\mathrm{K}-5 \mathrm{a} 2$, we looked for a second-generation backup compound for K-5a2, with the appropriate anti-HIV potency, significantly reduced hERG activity, decreased induction of the CYP enzyme, and improved aqueous solubility. Consequently, the N-propionylsulfonamide prodrug strategy was employed in a structural modification. The synthesis and characterization of prodrug HM-1 (Fig. 3), including antiviral activity, acute toxicity, subacute toxicity, hERG inhibition, and CYP enzymatic inhibitory activity, are presented in this paper.

\section{Methods}

\section{N-((4-((4-((4-(4-cyano-2,6-dimethylphenoxy)thieno[3,2- d]pyrimidin-2-yl)amino)piperidin-1- yl)methyl)phenyl)sulfonyl)propionamide (HM-1)}

$\mathrm{K}-5 \mathrm{a} 2(0.5 \mathrm{~g}, 0.9 \mathrm{mmol})$ was dissolved in propionic acid $(4 \mathrm{~mL})$ and propanoic anhydride $(1 \mathrm{~mL})$ was then added. The mixture was then stirred at $120^{\circ} \mathrm{C}$ for $2 \mathrm{~h}$ and checked by TLC until completion. The reaction solution was concentrated under reduced pressure and then extracted with dichloromethane $(20 \mathrm{~mL})$, washed with water $(2 \times 20 \mathrm{~mL})$ and brine $(20 \mathrm{~mL})$. The organic layer was dried over anhydrous $\mathrm{Na}_{2} \mathrm{SO}_{4}$, filtered, and the residue was purified by silica gel chromatography $\left(\mathrm{CH}_{2} \mathrm{Cl}_{2}: \mathrm{CH}_{3} \mathrm{OH}=30: 1\right)$ and then recrystallized from ethyl acetate/petroleum ether to give the title compound $\mathrm{HM}-1$ as white solid in $36 \%$ yield, mp $130-133^{\circ} \mathrm{C} .{ }^{1} \mathrm{H}$ NMR (400 MHz, DMSO- $\left.d_{6}\right)$ : $\delta 12.360-10.713\left(\mathrm{~m}, 1 \mathrm{H}, \mathrm{SO}_{2} \mathrm{NH}\right), 8.13(\mathrm{~d}, J=$ $5.4 \mathrm{~Hz}, 1 \mathrm{H}, \mathrm{C}_{6}$-thienopyrimidine-H), 7.79 (d, J=7.9 Hz, 2H, $\left.\mathrm{C}_{3}, \mathrm{C}_{5}-\mathrm{Ph}^{\prime}-\mathrm{H}\right), 7.65$ (s, 2H, $\left.\mathrm{C}_{3}, \mathrm{C}_{5}-\mathrm{Ph}^{\prime \prime}-\mathrm{H}\right), 7.45$ (d, J $\left.=8.0 \mathrm{~Hz}, 2 \mathrm{H}, \mathrm{C}_{2}, \mathrm{C}_{6}-\mathrm{Ph}^{\prime}-\mathrm{H}\right), 7.245-7.134\left(\mathrm{~m}, 1 \mathrm{H}, \mathrm{C}_{7}\right.$-thienopyrimidine-H), $6.86(\mathrm{~s}, 1 \mathrm{H}, \mathrm{NH}), 3.69(\mathrm{~s}, 1 \mathrm{H}), 3.51$ $\left(\mathrm{s}, 2 \mathrm{H}, \mathrm{N}-\mathrm{CH}_{2}\right), 2.784-2.622(\mathrm{~m}, J=35.5 \mathrm{~Hz}, 2 \mathrm{H}), 2.13(\mathrm{q}, J=7.5 \mathrm{~Hz}, 2 \mathrm{H}),, 2.04\left(\mathrm{~s}, 6 \mathrm{H}, \mathrm{CH}_{3} \times 2\right), 1.894-$ $1.1053(\mathrm{~m}, 6 \mathrm{H}), 0.82\left(\mathrm{t}, J=7.4 \mathrm{~Hz}, 3 \mathrm{H}, \mathrm{CH}_{3}\right) .{ }^{13} \mathrm{C}$ NMR $\left(100 \mathrm{MHz}, \mathrm{DMSO}-d_{6}\right)$ : $\delta 173.21,162.51,160.56$, 
$153.45,139.23,133.25,133.01,129.62,127.90,119.03,109.08,61.69,52.64,31.44,29.43,16.25,8.90$. ESI-MS: $\mathrm{m} / \mathrm{z} 605.43(\mathrm{M}+1) . \mathrm{C}_{30} \mathrm{H}_{32} \mathrm{~N}_{6} \mathrm{O}_{4} \mathrm{~S}_{2}(604.1926)$.

In vitro anti-HIV assay in TZM-bl cells

Different concentrations of K-5a2 and HM-1 were added to TZM-bl cells, which were infected by NL4-3 virus. After two days, remove the culture medium and then add $100 \mu \mathrm{L}$ of Bright Glo reagent.

Various concentrations of K-5a2 and HM-1 were affiliated to TZM-bl cells, and then incubated. Four days later, add XTT solution ( $1 \mathrm{mg} / \mathrm{mL})$, which involved $0.02 \mu \mathrm{M}$ PMS. The absorbance was detected at $450 \mathrm{~nm}$ four hours later. $\mathrm{EC}_{50}$ ( $50 \%$ effective concentration) was the concentration that caused a $50 \%$ decrease in luciferase activity, $\mathrm{CC}_{50}$ (50\% cytotoxic concentration) was concentration that caused a $50 \%$ reduction in cell viability.

In vitro anti-HIV assay in MT-4 cells

This kind of anti-HIV activity and cytotoxicity assay were conducted in MT-4 cells named MTT method. 10 different concentrations of K-5a2, HM-1 and reference drugs were added in the corresponding volumes to formulate two series of triplicate wells to evaluate anti-HIV activity simultaneously on mock- and HIVinfected cells. Serial 5-fold dilutions of relevant compounds were added in flat-bottomed 96-well microtiter trays. HIV stock at $100-300 \mathrm{CCID}_{50}$ or culture medium was added to the infected or mockinfected wells, and untreated HIV- and mock-infected cell samples were as controls. After the MT-4 cells being centrifuged, the supernatant was deserted. MT-4 cells were resuspended and transfer $50 \mu \mathrm{L}$ volumes for infecting. Five days later, MTT assay was conducted on mock-and HIV-infected cells. All data were calculated by the median absorbance value. $\mathrm{EC}_{50}$ was concentration achieving $50 \%$ protection against the cytopathic effect of the virus in infected cells, $\mathrm{CC}_{50}$ was the concentration reducing the absorbance (OD540) of the mock-infected control sample by $50 \%$.

\section{Metabolic stability in HLM and human plasma}

To validate our hypothesis, prodrug HM-1 was further assessed for its ability to undergo conversion to the parent drug K-5a2. HLM stability assay was primarily carried out. HM-1 incubated with microsome solution for 10 minutes, and then $2 \mathrm{mM} \mathrm{MgCl} 2$ was added. Each bioanalysis plate was sealed after adding into stop solution for LC-MS/MS analysis.

We also tested the stability of HM-1 in human plasma. Blank plasma spiked with HM-1 (100 $\mu \mathrm{M})$ was incubated at $37^{\circ} \mathrm{C}$. Stop solution was added at 0, 10, 30, 60 and 120 min. The supernatant was transferred from each well and mixed with ultra pure water for LC-MS/MS analysis.

\section{Measurements of water solubility and Log P}

Water solubility was measured in phosphate buffer at $\mathrm{pH} 7.4$ and 2.0 by using a HPLC-UV method. [16] $\mathrm{HM}-1$ or $\mathrm{K}-5 \mathrm{a} 2$ was dissolved in DMSO, and then spiked into $1 \mathrm{~mL}$ purified water. After ultrasonic for $2 \mathrm{~h}$, 
the saturated solution was filtrated through a filter membrane and prepared two samples. LC-20AT HPLCUV (SHIMADZU) system was used to compare the peak area of the saturated solution with a standard curve plotted peak area. Stock solution of HM-1 or K-5a2 were prepared for HPLC analysis. The P (partition coefficient) value was obtained by the peak area ratios in $n$-octanol and in $\mathrm{H}_{2} \mathrm{O}$.

\section{Assay procedures for $h E R G$ activity}

The hERG channels were stably expressed in Chinese Hamster Ovary $(\mathrm{CHO})$ cells that had no endogenous $\mathrm{IKr}$, so $\mathrm{CHO}$-hERG cells obtained from Sophion Biosciences were used in this assay. ${ }^{[17]} \mathrm{CHO}$-hERG cells were maintained at $37^{\circ} \mathrm{C}\left( \pm 2{ }^{\circ} \mathrm{C}\right)$ under $5 \% \mathrm{CO}_{2}(4 \% \sim 8 \%)$ in a high humidity incubator. The whole-cell patch-clamp technique was used to record hERG current controlled with Patchmaster Pro software at room temperature and output signals from the patch-clamp amplifier was digitized and low-pass filtered at $2.9 \mathrm{KHz}$. Electrode was recorded by a micropipette filled with ICS, which was drawn out from borosilicate glass to give a tip resistance between $3 \sim 5 \mathrm{M} \Omega$. The initial holding potential was $-80 \mathrm{mV}$, and then the voltage was increased to $+60 \mathrm{mV}$ for $850 \mathrm{~ms}$ to open the hERG channels. After that, the voltage was decreased to $-50 \mathrm{mV}$ for $1275 \mathrm{~ms}$ to cause a "rebound" or tail current, before the voltage was decreased to the holding potential $(-80 \mathrm{mV})$, the peak tail current was measured and collected for data analysis. This command voltage protocol was repeated every $15 \mathrm{~s}$ continuously.

\section{Acute and subacute toxicity experiment}

All animal treatments were performed strictly in accordance with the institutional guidelines of Animal Care and Use Committee at Shandong University, after gaining approval from the Animal Ethical and Welfare Committee (AEWC). Healthy male Kunming mice $(17 \sim 22 \mathrm{~g})$ were randomly divided into three groups: blank group, K-5a2 group, and HM-1 group. Each group consisted of 5 mice. K-5a2 and HM-1 were suspended in dimethyl sulfoxide (DMSO): normal saline: polyethylene glycol (PEG) $400=5 \%$ : 25\%: $70 \%$ at concentrations of $200 \mathrm{mg} \cdot \mathrm{mL}^{-1}$, respectively, and all mice had been fasted for $12 \mathrm{~h}$, and then the mice were given by gavage a dose of $2000 \mathrm{mg} / \mathrm{kg}$ of blank solvent, $\mathrm{K}-5 \mathrm{a} 2$ and $\mathrm{HM}-1$ respectively for the following 7 days. The death, body weight and behavioral abnormalities were monitored.

Another group of healthy male Kunming mice were also randomly divided into three groups: blank group, K-5a2 group, and HM-1 group. Each group consisted of 5 mice. Suspension of K-5a2 and HM-1 were prepared (DMSO: sodium carboxymethylcellulose: $\mathrm{H}_{2} \mathrm{O}=3 \%: 77 \%: 20 \%$ ), respectively, with concentrations of $6 \mathrm{mg} \cdot \mathrm{mL}^{-1}$, and administered intragastrically after the mice had been fasted for $12 \mathrm{~h}$. Before dosages of $60 \mathrm{mg} \cdot \mathrm{kg}^{-1}$ of blank solvent, $\mathrm{K}-5 \mathrm{a} 2$ and $\mathrm{HM}-1$ were administered respectively to three groups, and the body weight of the mice was measured. All of the mice were dissected on the last day, and the heart, liver, spleen, lung, and kidney were extracted. These organs were then examined by HE to see if any damage had occurred.

Kunming mice were purchased from the animal experimental center of Shandong University. Animals were maintained during the experiment in standard conditions of 12 hours light-dark cycle, food and water ad libitum, temperature $24^{\circ} \mathrm{C}$, humidity above $55 \%$. When the experiments finished, all animals 
were euthanized using the method of spinal dislocation. The details were as follow: grasp the mouse with the right hand and pull it backward hard, while pressing the mouse's head with the thumb and index finger of the left hand to pull the spinal cord and brain marrow to break, and the mouse died immediately.

\section{Cytochrome P450 inhibition assay}

Compound HM-1 and standard inhibitors (a-naphthoflavone, sulfaphenazole, (+)-N-3-benzylnirvanol, quinidine, ketoconazole) were prepared. Then, the substrates solutions, potassium phosphate buffer (PB), HM-1 and positive control working solution were added into homologous wells, respectively. Then, the HLM solutions pre-warmed for 10 min and NADPH cofactor were added. Before centrifuged, the $400 \mu \mathrm{L}$ cold stop solution was added and then $200 \mu \mathrm{L}$ supernatant was transferred for LC/MS/MS analysis.

\section{Results}

\section{Chemistry}

The synthetic routes of HM-1 was shown in Scheme 1, K-5a2 was prepared according to our previously reported method. ${ }^{[5]} \mathrm{HM}-1$ was synthesized from the 2,4-dichlorothiophene[3,2-d]pyrimidine (1); nucleophilic substitution reactions with 3,5-dimethyl-4-hydroxybenzonitrile and 4-(tert-butoxycarbonyl)aminopiperidine in the presence of $\mathrm{K}_{2} \mathrm{CO}_{3}$ and DMF afforded intermediate 3 . Then intermediate 3 underwent deprotection with trifluoroacetic acid at room temperature in DCM to generate compound $\mathbf{4}$, which led to $\mathrm{K}-5 \mathrm{a} 2$ with 4-bromomethylbenzenesulfonamide, $\mathrm{K}_{2} \mathrm{CO}_{3}$ and DMF. Then, $\mathrm{K}-5 \mathrm{a} 2(0.5 \mathrm{~g}$, $0.9 \mathrm{mmol})$ was dissolved in propionic acid $(4 \mathrm{~mL})$ and propanoic anhydride $(1 \mathrm{~mL})$ was then added. The mixture was then stirred at $120^{\circ} \mathrm{C}$ for $2 \mathrm{~h}$.

The target compound HM-1 was completely characterized by the spectral means including ${ }^{1} \mathrm{H} \mathrm{NMR},{ }^{13} \mathrm{C}$ NMR and MS. The purity was $>95 \%$ as determined by analytical HPLC.

\section{Anti-HIV activity assay in TZM-bl cells}

To examine the antiviral activity of $\mathrm{HM}-1$, along with $\mathrm{K}-5 \mathrm{a} 2$, reduction in luciferase gene expression was detected in TZM-bl cells. As exhibited in Table 1, the new compound HM-1 still revealed high potency suppressing $\mathrm{HIV}-1_{\mathrm{NL} 4-3}$ strain at a nanomolar concentration $\left(\mathrm{EC}_{50}=7.99 \mathrm{nM}\right)$, although it was inferior to that of the parent drug $\mathrm{K}-5 \mathrm{a} 2\left(\mathrm{EC}_{50}=1.17 \mathrm{nM}\right)$. The $\mathrm{CC}_{50}$ values of $\mathrm{HM}-1$ and $\mathrm{K}-5 \mathrm{a} 2$ were greater than $210 \mathrm{nM}$, which illustrated that both compounds had low cytotoxicity in TZM-bl cells.

Table 1

Antiviral potency against HIV-1 NL4-3 and cytotoxicity in TZM-bl cells.

\begin{tabular}{|llll|}
\hline Compds. & $\mathrm{EC}_{50}(\mathrm{nM}, \mathrm{NL4}-3)$ & $\mathrm{CC}_{50}(\mu \mathrm{M})$ & $\mathrm{SI}(\mathrm{NL4}-3)$ \\
\hline $\mathrm{K}-5 \mathrm{a} 2$ & $1.17 \pm 0.44$ & $>0.23$ & $>196.58$ \\
$\mathrm{HM}-1$ & $7.99 \pm 2.73$ & $>0.21$ & $>26.28$ \\
\hline
\end{tabular}




\section{Anti-HIV activity assay in MT-4 cells}

Furthermore, we also evaluate the anti-HIV-1 potency against wild type (WT) and common mutant strains in MT-4 cells. The results in Table 2 showed that HM-1 still exhibited high antiviral activity against HIV$1_{\text {IIIIB }}$ with $\mathrm{EC}_{50}$ values of $2.9 \mathrm{nM}$, which was better than the reference drug $\mathrm{ETR}\left(\mathrm{EC}_{50}=3.0 \mathrm{nM}\right)$. Besides, the cytotoxicity of HM-1 $\left(\mathrm{CC}_{50}=75.7 \mu \mathrm{M}, \mathrm{SI}=26161\right)$ in MT-4 cells was far lower than ETR $\left(\mathrm{CC}_{50}>4.6 \mu \mathrm{M}\right.$, SI > 1546). And HM-1 didn't show inhibitory against HIV-2 strain.

Table 2

Antiviral potency against WT and cytotoxicity in MT-4 cells.

\begin{tabular}{|c|c|c|c|c|}
\hline \multirow[t]{2}{*}{ Compds. } & \multicolumn{2}{|l|}{$\mathrm{EC}_{50}(\mathrm{nM})$} & \multirow[t]{2}{*}{$\mathrm{CC}_{50}(\mu \mathrm{M})$} & \multirow[t]{2}{*}{ SI (IIIB) } \\
\hline & IIIB & ROD & & \\
\hline $\mathrm{HM}-1$ & $2.9 \pm 0.4$ & $>7127.0$ & $75.7 \pm 24.1$ & 26161 \\
\hline K-5a2 & $1.4 \pm 0.2$ & $>227819.5$ & $>227.9$ & $>161290$ \\
\hline NVP & $84.0 \pm 10.7$ & - & $>9.5$ & $>113$ \\
\hline AZT & $18.3 \pm 4.2$ & - & $>7.5$ & $>410$ \\
\hline EFV & $2.5 \pm 0.8$ & -- & $>6.3$ & $>2572$ \\
\hline ETR & $3.0 \pm 0.6$ & - & $>4.6$ & $>1546$ \\
\hline
\end{tabular}

As showed in Table 3, HM-1 exhibited higher anti-HIV-1 activities towards mutant strains than ETR except RES056 strain. Notably, the potency against Y181C strain of HM-1 $\left(E_{50}=5.5 \mathrm{nM}\right)$ was superior to the parent K-5a2 $\left(\mathrm{EC}_{50}=5.9 \mathrm{nM}\right)$. 
Table 3

Antiviral potency against mutant strains in MT-4 cells.

\begin{tabular}{|c|c|c|c|c|c|c|c|}
\hline \multirow[t]{2}{*}{ Compds. } & \multicolumn{7}{|c|}{$\mathrm{EC}_{50}(\mathrm{nM})$} \\
\hline & L100I & K103N & Y181C & Y188L & E138K & F227L/V106A & RES056 \\
\hline HM-1 & $4.7 \pm 1.4$ & $2.1 \pm 0.6$ & $5.5 \pm 1.8$ & $5.6 \pm 2.2$ & $\begin{array}{l}8.5 \pm \\
4.0\end{array}$ & $6.9 \pm 2.9$ & $\begin{array}{l}101.6 \pm \\
34.4\end{array}$ \\
\hline K-5a2 & $3.2 \pm 0.8$ & $1.2 \pm 0.2$ & $5.9 \pm 0.9$ & $3.7 \pm 0.7$ & $\begin{array}{l}4.6 \pm \\
1.1\end{array}$ & $3.6 \pm 0.8$ & $\begin{array}{l}53.5 \pm \\
20.2\end{array}$ \\
\hline NVP & $\begin{array}{l}372.9 \pm \\
154.4\end{array}$ & $\begin{array}{l}1470.7 \pm \\
457.9\end{array}$ & $\begin{array}{l}2325.1 \pm \\
1074.2\end{array}$ & $\begin{array}{l}3388.2 \pm \\
1331.0\end{array}$ & $\begin{array}{l}72.8 \pm \\
20.6\end{array}$ & $\begin{array}{l}2730.3 \pm \\
1258.4\end{array}$ & $\begin{array}{l}6747.7 \\
\pm \\
2322.7\end{array}$ \\
\hline AZT & $7.0 \pm 2.6$ & $12.6 \pm 3.4$ & $8.7 \pm 1.7$ & $9.9 \pm 7.8$ & $\begin{array}{l}14.5 \pm \\
2.7\end{array}$ & $4.7 \pm 1.7$ & $\begin{array}{l}20.1 \pm \\
4.7\end{array}$ \\
\hline EFV & $\begin{array}{l}30.8 \pm \\
18.4\end{array}$ & $\begin{array}{l}63.7 \pm \\
14.6\end{array}$ & $5.2 \pm 1.7$ & $\begin{array}{l}148.3 \pm \\
40.8\end{array}$ & $\begin{array}{l}5.7 \pm \\
1.2\end{array}$ & $168.5 \pm 63.9$ & $\begin{array}{l}273.2 \pm \\
153.4\end{array}$ \\
\hline ETR & $\begin{array}{l}10.2 \pm \\
10.3\end{array}$ & $2.3 \pm 0.4$ & $14.0 \pm 2.6$ & $15.5 \pm 6.8$ & $\begin{array}{l}9.8 \pm \\
3.8\end{array}$ & $8.2 \pm 2.2$ & $\begin{array}{l}60.2 \pm \\
24.7\end{array}$ \\
\hline
\end{tabular}

Metabolic stability assays

Since the prodrug Parecoxib with the N-propionyl moiety was rapidly hydrolyzed by the liver to valdecoxib, ${ }^{[18]}$ the stability of N-propionylsulfonamide prodrug HM-1 in the presence of HLM was determined. The results demonstrated that $\mathrm{HM}-1$ was rapidly converted to the parent drug K-5a2 in 10 min. In addition, HM-1 was highly stabilized in human plasma via plasma stability assay (Table 4).

Table 4

The metabolic stability of HM-1 in HLM and human plasma.

\begin{tabular}{|lllll|}
\hline Compd. & Metabolite & Time Point (min) & Analyte/IS & Metabolite formation \\
\hline HM-1 (HLM) & K-5a2 & 0 & 0.004 & $2.1 \%$ \\
& & 2 & 0.093 & $53.0 \%$ \\
& & 5 & 0.146 & $83.4 \%$ \\
& & 0.179 & $102.2 \%$ \\
& & 30 & 0.192 & $109.2 \%$ \\
\hline & & 0.179 & $102.0 \%$ \\
\hline
\end{tabular}

As well known, poor water solubility and hydrophilicity/lipophilicity will influence drug metabolism and distribution, $\mathrm{K}-5 \mathrm{a} 2$ displayed poor solubility which can limit its further development as a drug. HPLC was 
used to test the solubility and $\log \mathrm{P}$ of $\mathrm{K}-5 \mathrm{a} 2$ and $\mathrm{HM}-1$, and other drug-like properties such as $\mathrm{MW}$ (molecular weight) and nON (no. of hydrogen bond acceptors) were predicted (Table 5).Surprisingly, HM-1 showed a > 70-fold improvement in aqueous solubility compared to K-5a2, which supported that the strategy of N-propionylsulfonamide can improve water solubility effectively.

Table 5

Main physicochemical properties of K-5a2, HM-1 and ETV.

\begin{tabular}{|c|c|c|c|c|}
\hline Compd. & Metabolite & $\begin{array}{l}\text { Time Point } \\
(\min )\end{array}$ & $\begin{array}{l}\% \\
\text { Remaining }\end{array}$ & $\begin{array}{l}\text { Formation of Metabolite } \\
(\mathrm{nM})\end{array}$ \\
\hline \multirow{5}{*}{$\begin{array}{l}\text { HM-1 (human } \\
\text { plasma) }\end{array}$} & \multirow[t]{5}{*}{$\mathrm{K}-5 \mathrm{a} 2$} & 0 & 100 & 2.2281 \\
\hline & & 10 & 101.99 & 2.377 \\
\hline & & 30 & 103.56 & 3.244 \\
\hline & & 60 & 100.54 & 3.817 \\
\hline & & 120 & 108.58 & 2.898 \\
\hline Parameters & $\begin{array}{l}\text { Rule of } \\
\text { five }\end{array}$ & K-5a2 & $\mathrm{HM}-1$ & ETV \\
\hline MW & $<500$ & 548.68 & 604.74 & 435.28 \\
\hline $\mathrm{nON}$ & $<10$ & 9 & 10 & 7 \\
\hline $\mathrm{nOHNH}$ & $<5$ & 3 & 2 & 3 \\
\hline nrotb & $\leq 10$ & 7 & 9 & 4 \\
\hline tPSA & $<140$ & 134.24 & 137.31 & 120.65 \\
\hline $\log \mathrm{P}$ & $<5$ & $3.33^{\mathrm{a}}$ & -0.11 & $>5^{b}$ \\
\hline Solubility $(\mathrm{pH}=7.0)$ & & $<1$ & 69.66 & \\
\hline Solubility $(\mathrm{pH}=7.4)^{\mathrm{d}}$ & & $<0.1$ & 162.64 & $<1^{b}$ \\
\hline Solubility $(\mathrm{pH}=2.0)^{\mathrm{d}}$ & & ND & 18.09 & $<<1^{b}$ \\
\hline $\mathrm{mp}$ & & $223-225^{\circ} \mathrm{C}$ & $130-133^{\circ} \mathrm{C}$ & $255-257^{\circ} \mathrm{C}^{\mathrm{C}}$ \\
\hline
\end{tabular}

aUsing free on-line software (http://www.molinspiration.com/); $\mathrm{MW}=$ molecular weight; $\mathrm{nON}=$ no. of hydrogen bond acceptors; $\mathrm{nOHNH}=$ no. of hydrogen bond donors; nrotb = no. of rotatable bonds; tPSA = topological polar surface area; $\log P=\operatorname{logarithm}$ of partition coefficient; ND = not determined. ${ }^{b}$ See Ref [19]. 'See Ref [20]. 'Measured in phosphate buffer by HPLC in duplicate

\section{Assessment of hERG activity}

Acquired long QT syndrome caused by inhibition of the voltage-dependent ion channel, which is encoded by human ether-a-go-go-related gene ( $h E R G$ ), is a critical adverse effect of noncardiovasular therapeutic 
drugs. ${ }^{[21]}$ As we all know, decreasing alkalinity is an important strategy for structure optimization of lead compounds to reduce the inhibitory activity of hERG. ${ }^{[22]}$ Through predicting by ChemDraw, the alkalinity of HM-1 was decreased, which revealed that HM-1 may have lower hERG activity. Indeed, in vitro manual patch-clamp electrophysiology was used to evaluate the activity against the hERG potassium channel to estimate the potential risk for cardiotoxicity, ${ }^{[23]}$ and the result verified our prediction exactly.

As shown in Fig. 4, $\mathrm{HM}-1$ showed an $\mathrm{IC}_{50}$ value of $6.39 \mu \mathrm{M}$ against the potassium channel, which was nearly 50 times higher than that of $\mathrm{K}-5 \mathrm{a} 2\left(\mathrm{IC}_{50}=0.13 \mu \mathrm{M}\right)$. Although the $\mathrm{hERG} I \mathrm{IC}_{50}$ value of $\mathrm{HM}-1$ was not greater than $10 \mu \mathrm{M}$, it was also 12 times better than rilpivirine (RPV, IC $\left.{ }_{50}=0.5 \mu \mathrm{M}\right) .{ }^{[24]}$ Therefore, the hERG inhibitory activity of HM-1 was much lower than that of K-5a2, suggesting that the potential cardiotoxicity was significantly diminished.

\section{Assessment of acute and subacute toxicity.}

Regarding the relatively low cytotoxicity of $\mathrm{K}-5 \mathrm{a} 2$, a single-dose acute toxicity trial of $\mathrm{HM}-1$ in healthy Kunming mice was carried out. One mouse died after intragastric administration of K5a2 and $\mathrm{HM}-1$ at a dose of $2000 \mathrm{mg} / \mathrm{kg}$. However, no significant behavior abnormalities (lethargy, clonic convulsion, anorexia, and ruffed fur) were observed and the body weights changes was the same as in the blank group (Fig. 5A). Therefore, HM-1 can be tolerated at a dose of $2000 \mathrm{mg} / \mathrm{kg}$ with low toxicity.

To further evaluate the in vivo safety of HM-1, the subacute toxicity was investigated in healthy mice. No mice died, and no behavioral abnormalities occurred during the treatment period of mice treated po with $60 \mathrm{mg} / \mathrm{kg} \cdot$ day $^{-1}$ of HM-1 for 2 weeks. The body weight of mice in the HM-1 group increased gradually and the mice grew normally as in the $\mathrm{K}-5 \mathrm{a} 2$ group (Fig. 5B). Additionally, organs toxicity experiments were carried out by hematoxylin - eosin (HE) staining after dissecting all the mice. As depicted in Fig. 5C, the heart, liver, and spleen of the mice were not damaged with either HM-1 or K-5a2, but after treatment with $\mathrm{K}-5 \mathrm{a} 2$, it was remarkable that there were alveolar hemorrhage and alveolar interstitial thickening (red arrows) in the lung and glomerular edema (blue circles) in the kidney, which were obviously improved with $\mathrm{HM}-1$. The subacute toxicity assessment results indicated that $\mathrm{HM}-1$ possessed favorable in vivo safety profiles.

\section{In vitro effects of HM-1 on CYP enzymatic inhibitory activity.}

In the liver, the majority of drugs are metabolized by enzymes like cytochrome P450 enzymes, whose activity can be inhibited or induced by drugs. Therefore, when co-administering different drugs, therapeutic effect may be decreased or increased, this is called metabolism-mediated drug - drug interactions (DDI). Previous studies disclosed that ETR is an inducer of CYP3A4 and inhibitor of CYP2C9 and CYP2C19, and DDI will occur when ETR is co-administrated with other anti-HIV-1drugs, which limits the selection of concomitant antiretrovirals. Hence, HM-1 was evaluated for its ability to inhibit CYP drugmetabolizing enzymes in vitro. 
As shown in Table 6 and Table 7, the CYP3A4 inhibition of HM-1 $\left(\mathrm{IC}_{50}>50 \mu \mathrm{M}\right)$ was far superior to K-5a2 $\left(\mathrm{IC}_{50}=18.9 \mu \mathrm{M}\right)$, which revealed that HM-1 might decrease toxicity and DDI caused by CYP3A4 inhibition in anti-HIV infection. In addition, HM-1 displayed no CYP enzymatic inhibition of CYP1A2 and CYP2D6. Although the CYP2C9 and CYP2C19 inhibitions $\left(\mathrm{IC}_{50}<3 \mu \mathrm{M}\right)$ of $\mathrm{HM}-1$ were inferior to $\mathrm{K}-5 \mathrm{a} 2,{ }^{[25]}$ which may induce side effects in the liver and probably result in DDI when co-administered with other different drugs, the perfect result of CYP3A4 inhibition was still worthy to emphasized.

Table 6

Inhibitory activity on CYP1A2, CYP2C9, CYP2C19, CYP2D6, and CYP3A4 of $\mathrm{HM}-1$ and positive controls

\begin{tabular}{|lllll|}
\hline CYP isozyme & Standard inhibitor & $\mathrm{IC}_{\mathbf{5 0}}(\mu \mathrm{M})$ & Compd. & $\mathrm{IC}_{50}(\mu \mathrm{M})$ \\
\hline 1A2 & a-naphthoflavone & 0.216 & $\mathrm{HM}-1$ & $>50$ \\
\hline 2C9 & sulfaphenazole & 0.609 & $\mathrm{HM}-1$ & 1.24 \\
\hline 2C19 & (+)-N-3-benzylnirvanol & 0.227 & $\mathrm{HM}-1$ & 1.83 \\
\hline 2D6 & quinidine & 0.134 & $\mathrm{HM}-1$ & $>50$ \\
\hline 3A4 & ketoconazole & 0.0375 & $\mathrm{HM}-1$ & $>50$ \\
\hline
\end{tabular}

Table 7

Inhibitory activity on CYP1A2, CYP2C9, CYP2C19, CYP2D6, and CYP3A4 of K$5 \mathrm{a} 2$ and positive controls

\begin{tabular}{|lllll|}
\hline CYP isozyme & Standard inhibitor & $\mathrm{IC}_{50}(\mu \mathrm{M})$ & Compd. & $\mathrm{IC}_{50}(\mu \mathrm{M})$ \\
\hline 1A2 & a-naphthoflavone & 0.311 & $\mathrm{~K}-5 \mathrm{a} 2$ & $>50$ \\
\hline 2C9 & sulfaphenazole & 0.643 & $\mathrm{~K}-5 \mathrm{a} 2$ & $>50$ \\
\hline 2C19 & (+)-N-3-benzylnirvanol & 0.259 & $\mathrm{~K}-5 \mathrm{a} 2$ & $>50$ \\
\hline 2D6 & quinidine & 0.158 & $\mathrm{~K}-5 \mathrm{a} 2$ & $>50$ \\
\hline 3A4 & ketoconazole & 0.0433 & $\mathrm{~K}-5 \mathrm{a} 2$ & 18.9 \\
\hline Tables & & & & \\
\hline
\end{tabular}

\section{Discussion}

A high-quality drug should emerge balanced efficacy against its therapeutic targets, safety, physicochemical properties and ADME properties. ${ }^{[26]}$ In order to improve key drug-like properties, namely the solubility, an effort to identify prodrugs was undertaken. This has led to the discovery of a $\mathrm{N}$ propionylsulfonamide prodrug HM-1. HM-1 could be rapidly converted to the parent drug $\mathrm{K}-5 \mathrm{a} 2$ in the liver, and exhibit remarkable potency against $\mathrm{HIV}-1_{\mathrm{NL4}-3}$ strain with an $\mathrm{EC}_{50}$ value of $7.99 \mathrm{nM}$. Furthermore, $\mathrm{HM}-1$ also showed excellent potency against $\mathrm{HIV}-1_{\text {IIIB }}\left(\mathrm{EC}_{50}=2.9 \mathrm{nM}\right)$ and $\mathrm{HIV}-1_{\mathrm{Y} 181 \mathrm{C}}$ strain 
$\left(\mathrm{EC}_{50}=5.5 \mathrm{nM}\right)$. The physicochemical evaluation showed that $\mathrm{HM}-1$ exhibited a 70 -fold increase in aqueous solubility $(69.66 \mu \mathrm{g} / \mathrm{mL})$ when compared to that of K-5a2 $(<<1 \mu \mathrm{g} / \mathrm{mL})$. The hERG liability $\left(\mathrm{IC}_{50}\right.$ $=6.39 \mu \mathrm{M})$ of $\mathrm{HM}-1$ was significantly reduced by 50 times, compared to $\mathrm{K}-5 \mathrm{a} 2\left(\mathrm{IC}_{50}=0.13 \mu \mathrm{M}\right)$, which would allow higher doses to be used in the clinic thereby realizing full potential of this compound. In addition, $\mathrm{HM}-1$ showed a low acute toxicity in mice $\left(\mathrm{LD}_{50}>2 \mathrm{~g} \cdot \mathrm{kg}^{-1}\right)$ as well as no obvious organ damage detected in the assessment of subacute toxicity.

\section{Conclusion}

In summary, the N-propionylsulfonamide prodrug approach has wide applicability in sulfonamide-bearing compounds and provides an effective means of augmenting the therapeutic potential of our anti-HIV-1 drug candidate $\mathrm{K}-5 \mathrm{a} 2$. What can not be ignored is that $\mathrm{HM}-1$ may induce some side effects in the liver and DDI probably occur when co-administrated with other drugs with an $\mathrm{IC}_{50}$ value less than $3 \mu \mathrm{M}$ against CYP2C9 and CYP2C19. Thus, further studies should be carried out to discover potential prodrugs with improved physiochemical and PK properties, as well as decreased induction of CYP enzymes.

\section{Abbreviations}

$\mathrm{CC}_{50}, 50 \%$ cytotoxicity concentration; $\mathrm{EC}_{50}$, the concentration causing $50 \%$ inhibition of antiviral activity; ETR, etravirine; HAART, highly active antiretroviral therapy; hERG, human ether-a-go-go-related gene; HIV-1, human immunodeficiency virus type $1 ; \mathrm{HLM}$, human liver microsomes. NNRTIs, non-nucleoside reverse transcriptase inhibitors; RPV, rilpivirine; SI, selection index; WT, wild-type.

\section{Declarations}

\section{Declarations}

Author declares that there is no conflict of interests.

\section{Ethics approval and consent to participate}

We performed this study with an authorized standard method to detect acute and subacute toxicity using mice and accredited by Laboratory Animal Ethical and Welfare Committee of Shandong University Cheeloo College of Medicine.

\section{Consent to publish}

Not applicable.

\section{Availability of data and materials}

All data obtained and analyzed during this work are included in this article. Extra information is available upon reasonable request from the corresponding author. 


\section{Competing interests}

The authors declare no competing financial interest.

\section{Funding}

Financial support from the National Natural Science Foundation of China (NSFC Nos. 81273354, 81573347), Key Project of NSFC for International Cooperation (No.81420108027), Young Scholars Program of Shandong University (YSPSDU No. 2016WLJH32), Key research and development project of Shandong Province (No. 2017CXGC1401).

\section{Authors' contributions}

$P Z$ and $X L$ provided part of the funding support and revised the manuscript. $X Z$ designed and performed research and wrote the final manuscript. $Z \mathrm{ZH}$ analyzed the data. DK, EDC and CP revised the manuscript. $\mathrm{TZ}$ performed the organs toxicity experiments. $\mathrm{CHC}$ and $\mathrm{KHL}$ performed the anti-HIV activity assay. All authors read and approved the final manuscript.

\section{Acknowledgments}

Not applicable.

\section{References}

[1] P. Zhan, C. Pannecouque, E. De Clercq, X. Liu, Anti-HIV drug discovery and development: current innovations and future trends, Journal of medicinal chemistry, 59 (2016) 2849-2878.

[2] T.L. Hartman, R.W. Buckheit, Jr., The Continuing evolution of HIV-1 therapy: identification and development of novel antiretroviral agents targeting viral and cellular targets, Molecular biology international, 2012 (2012) 401965.

[3] X. Zuo, Z. Huo, D. Kang, G. Wu, Z. Zhou, X. Liu, P. Zhan, Current insights into anti-HIV drug discovery and development: a review of recent patent literature (2014-2017), Expert opinion on therapeutic patents, 28 (2018) 299-316.

[4] D. Kang, Z. Fang, B. Huang, X. Lu, H. Zhang, H. Xu, Z. Huo, Z. Zhou, Z. Yu, Q. Meng, G. Wu, X. Ding, Y. Tian, D. Daelemans, E. De Clercq, C. Pannecouque, P. Zhan, X. Liu, Structure-based optimization of thiophene[3,2-d]pyrimidine derivatives as potent HIV-1 non-nucleoside reverse transcriptase inhibitors with improved potency against resistanceassociated variants, Journal of medicinal chemistry, 60 (2017) 4424-4443.

[5] D. Kang, Z. Fang, Z. Li, B. Huang, H. Zhang, X. Lu, H. Xu, Z. Zhou, X. Ding, D. Daelemans, E. De Clercq, C. Pannecouque, P. Zhan, X. Liu, Design, synthesis, and 
evaluation of thiophene[3,2-d]pyrimidine derivatives as HIV-1 non-nucleoside reverse transcriptase inhibitors with significantly improved drug resistance profiles, Journal of medicinal chemistry, 59 (2016) 7991-8007.

[6] S.N. Bhattachar, L.A. Deschenes, J.A. Wesley, Solubility: it's not just for physical chemists, Drug discovery today, 11 (2006) 1012-1018.

[7] M. Ishikawa, Y. Hashimoto, Improvement in aqueous solubility in small molecule drug discovery programs by disruption of molecular planarity and symmetry, Journal of medicinal chemistry, 54 (2011) 1539-1554.

[8] B. Huang, X. Liu, Y. Tian, D. Kang, Z. Zhou, D. Daelemans, E. De Clercq, C. Pannecouque, P. Zhan, X. Liu, First discovery of a potential carbonate prodrug of NNRTI drug candidate RDEA427 with submicromolar inhibitory activity against HIV-1 K103N/Y181C double mutant strain, Bioorganic \& medicinal chemistry letters, 28 (2018) $1348-1351$.

[9] Z. Guo, Strategy of molecular design of drugs: the unification of macro-properties and micro-structures of a molecule, Acta pharmaceutica Sinica, 43 (2008) 227-233.

[10] J. Rautio, H. Kumpulainen, T. Heimbach, R. Oliyai, D. Oh, T. Jarvinen, J. Savolainen, Prodrugs: design and clinical applications, Nature reviews drug discovery, 7 (2008) 255270.

[11] Z. Li, J. Wang, Y. Zhou, H. Liu, Lead compound optimization strategy (3)--Structure modification strategies for improving water solubility, Acta pharmaceutica Sinica, 49 (2014) 1238-1247.

[12] B. Huang, D. Kang, J. Yang, P. Zhan, X. Liu, Novel diarylpyrimidines and diaryltriazines as potent HIV-1 NNRTIs with dramatically improved solubility: a patent evaluation of US20140378443A1, Expert opinion on therapeutic patents, 26 (2016) 281289.

[13] M. Liu, Q. Yu, P. Li, M. Zhu, M. Fang, B. Sun, M. Sun, Y. Sun, P. Zhang, Z. He, J. Sun, Y. Wang, X. Liu, Simultaneous determination of parecoxib sodium and its active metabolite valdecoxib in rat plasma by UPLC-MS/MS and its application to a pharmacokinetic study after intravenous and intramuscular administration, Journal of chromatography. B, Analytical technologies in the biomedical and life sciences, 1022 (2016) 220-229.

[14] Z.T. Al-Salama, Elsulfavirine: first global approval, Drugs, 77 (2017) 1811-1816.

[15] Z. Dang, W. Lai, K. Qian, P. Ho, K.H. Lee, C.H. Chen, L. Huang, Betulinic acid derivatives as human immunodeficiency virus type 2 (HIV-2) inhibitors, Journal of medicinal 
chemistry, 52 (2009) 7887-7891.

[16] H. Zhang, Y. Tian, D. Kang, Z. Huo, Z. Zhou, H. Liu, E. De Clercq, C. Pannecouque, P. Zhan, X. Liu, Discovery of uracil-bearing DAPYs derivatives as novel HIV-1 NNRTIs via crystallographic overlay-based molecular hybridization, European journal of medicinal chemistry, 130 (2017) 209-222.

[17] J.T. Milnes, H.J. Witchel, J.L. Leaney, D.J. Leishman, J.C. Hancox, Investigating dynamic protocol-dependence of hERG potassium channel inhibition at 37 degrees C: Cisapride versus dofetilide, Journal of pharmacological and toxicological methods, 61 (2010) 178-191.

[18] N.M. Gajraj, COX-2 inhibitors celecoxib and parecoxib: valuable options for postoperative pain management, Current topics in medicinal chemistry, 7 (2007) 235-249.

[19] I. Weuts, F. Van Dycke, J. Voorspoels, S. De Cort, S. Stokbroekx, R. Leemans, M.E. Brewster, D. Xu, B. Segmuller, Y.T. Turner, C.J. Roberts, M.C. Davies, S. Qi, D.Q. Craig, M. Reading, Physicochemical properties of the amorphous drug, cast films, and spray dried powders to predict formulation probability of success for solid dispersions: etravirine, Journal of pharmaceutical sciences, 100 (2011) 260-274.

[20] S. Joshi, G.C. Maikap, S. Titirmare, A. Chaudhari, M.K. Gurjar, An improved synthesis of etravirine, Organic Process Research \& Development, 14 (2010) 657-660.

[21] D. Kang, H. Zhang, Z. Wang, T. Zhao, T. Ginex, F.J. Luque, Y. Yang, G. Wu, D. Feng, F. Wei, J. Zhang, E. De Clercq, C. Pannecouque, C.H. Chen, K.H. Lee, N.A. Murugan, T.A. Steitz, P. Zhan, X. Liu, Identification of dihydrofuro[3,4- d]pyrimidine derivatives as novel HIV-1 non-nucleoside reverse transcriptase inhibitors with promising antiviral activities and desirable physicochemical properties, Journal of medicinal chemistry, 62 (2019) 1484-1501.

[22] S.B. Zhou, J. Wang, H. Liu, Lead compound optimization strategy(5) - reducing the hERG cardiac toxicity in drug development, Acta pharmaceutica Sinica, 51 (2016) 15301539.

[23] B. Huang, W. Chen, T. Zhao, Z. Li, X. Jiang, T. Ginex, D. Vilchez, F.J. Luque, D. Kang, P. Gao, J. Zhang, Y. Tian, D. Daelemans, E. De Clercq, C. Pannecouque, P. Zhan, X. Liu, Exploiting the tolerant region I of the non-nucleoside reverse transcriptase inhibitor (NNRTI) binding pocket: discovery of potent diarylpyrimidine-typed HIV-1 NNRTIs against wild-type and E138K mutant virus with significantly improved water solubility and favorable safety profiles, Journal of medicinal chemistry, 62 (2019) 2083-2098.

[24] D. Kang, Z. Huo, G. Wu, J. Xu, P. Zhan, X. Liu, Novel fused pyrimidine and isoquinoline derivatives as potent HIV-1 NNRTIs: a patent evaluation of WO2016105532A1, 
WO2016105534A1 and WO2016105564A1, Expert opinion on therapeutic patents, 27 (2017) 383-391.

[25] L.H. Cohen, M.J. Remley, D. Raunig, A.D. Vaz, In vitro drug interactions of cytochrome p450: an evaluation of fluorogenic to conventional substrates, Drug metabolism and disposition: the biological fate of chemicals, 31 (2003) 1005-1015.

[26] G. Wu, T. Zhao, D. Kang, J. Zhang, Y. Song, V. Namasivayam, J. Kongsted, C. Pannecouque, E. De Clercq, V. Poongavanam, X. Liu, P. Zhan, Overview of recent strategic advances in medicinal chemistry, Journal of medicinal chemistry, (2019). DOI: 10.1021/acs.jmedchem.9b00359.

\section{Figures}

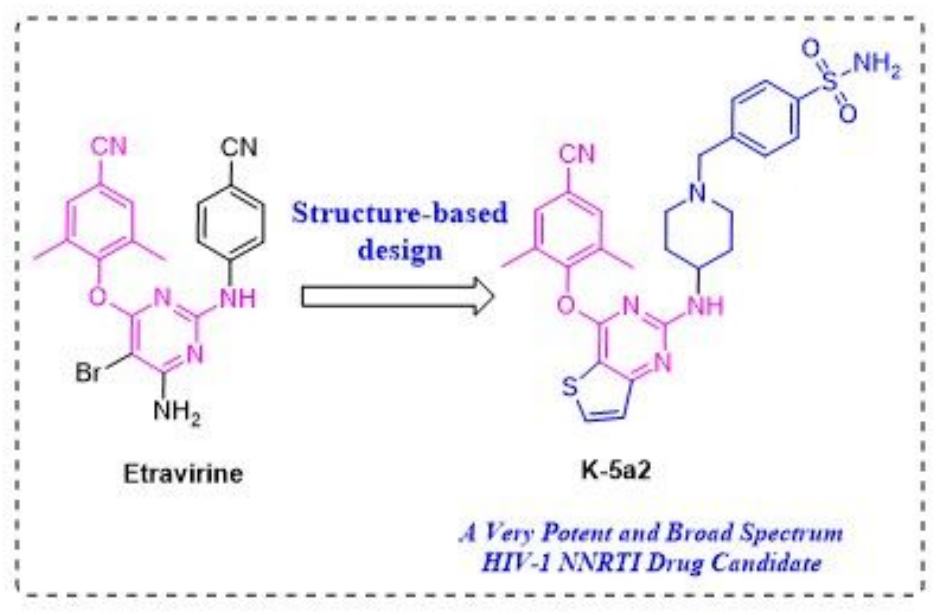

K-5a2

$\mathrm{EC}_{9_{0}}(\mathrm{nM})=$

1.4 (WT):

3.4 (L100I);

$2.9(\mathrm{~K} 103 \mathrm{~N})$;

3.2 (Y18IC);

3.0 (Y188L)

2.9 (El38K);

4.2 (F227L+V106A);

$30.6(\mathrm{~K} 103 \mathrm{~N}+\mathrm{Y} 181 \mathrm{C})$.

SI $>159101$ (WT)
Etravirine

$\mathrm{EC}_{50}(\mathrm{nM})=$

4.1 (WT);

5.4 (L100I);

$2.4(\mathrm{~K} 103 \mathrm{~N})$;

15.8 (Y181C);

20.5 (Y188L);

14.4 (E138K);

29.4 (F227L+V106A);

$17(\mathrm{~K} 103 \mathrm{~N}+\mathrm{Y} 181 \mathrm{C})$;

SI $>1128$ (WT)

Figure 1. The discovery of K-5a2 and its anti-HIV-1 activities.

\section{Figure 1}

The discovery of $\mathrm{K}-5 \mathrm{a} 2$ and its anti-HIV-1 activities. 


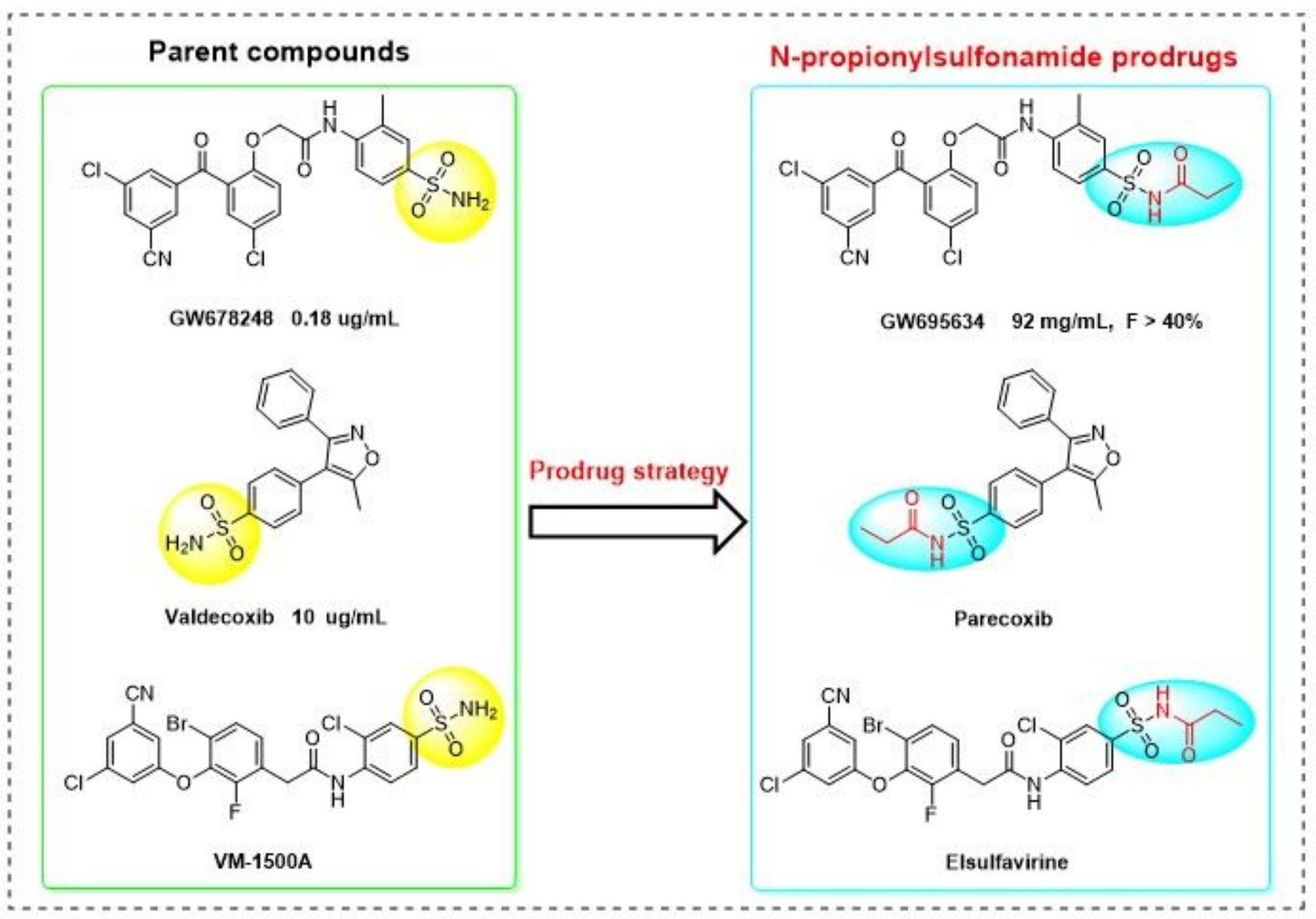

Figure 2. Structures of successful N-propionyl sulfonamide prodrugs

Figure 2

Structures of successful N-propionyl sulfonamide prodrugs 
<smiles>C=CCN1CCC(Nc2nc(Oc3ccc(C#N)cc3C)c3sccc3n2)CC1</smiles>

K-5a2

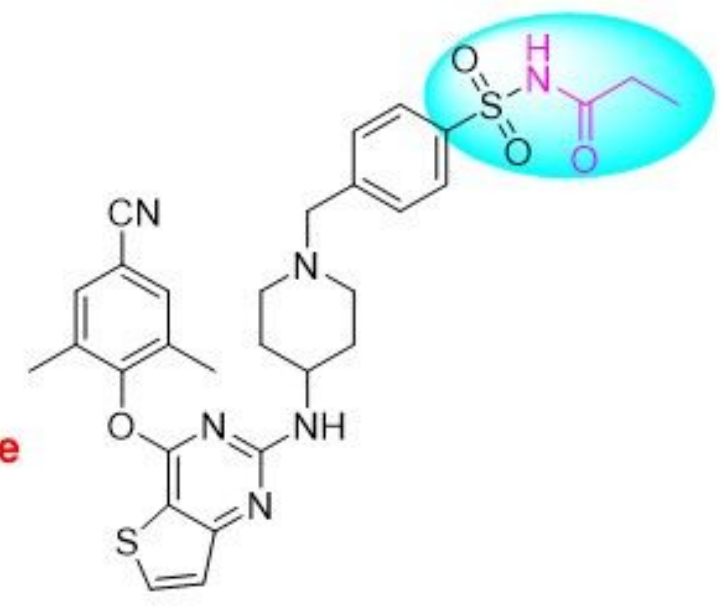

HM-1 (K-5a2 prodrug)

Figure 3. The design concept of K-5a2 prodrug.

\section{Figure 3}

The design concept of $\mathrm{K}-5 \mathrm{a} 2$ prodrug.
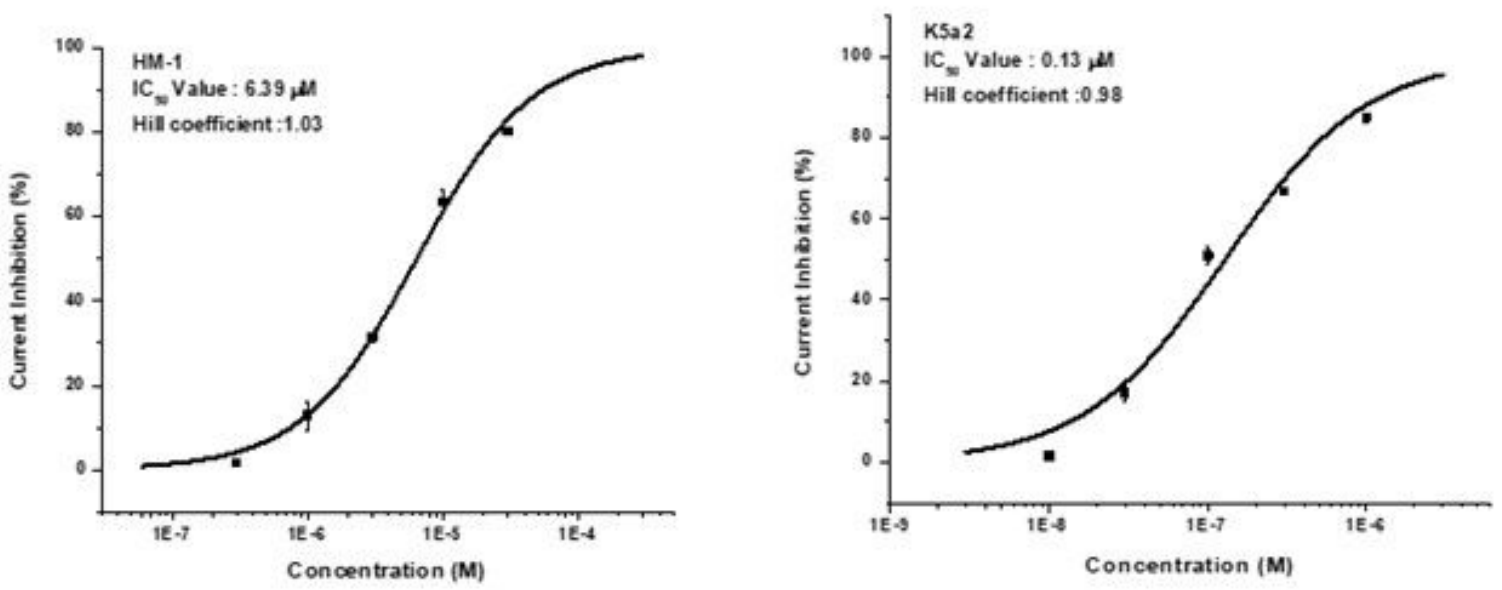

Figure 4. Activity of HM-1 and K-5a2 against hERG potassium channel in CHO-hERG cells.

\section{Figure 4}

Activity of HM-1 and K-5a2 against hERG potassium channel in CHO-hERG cells. 


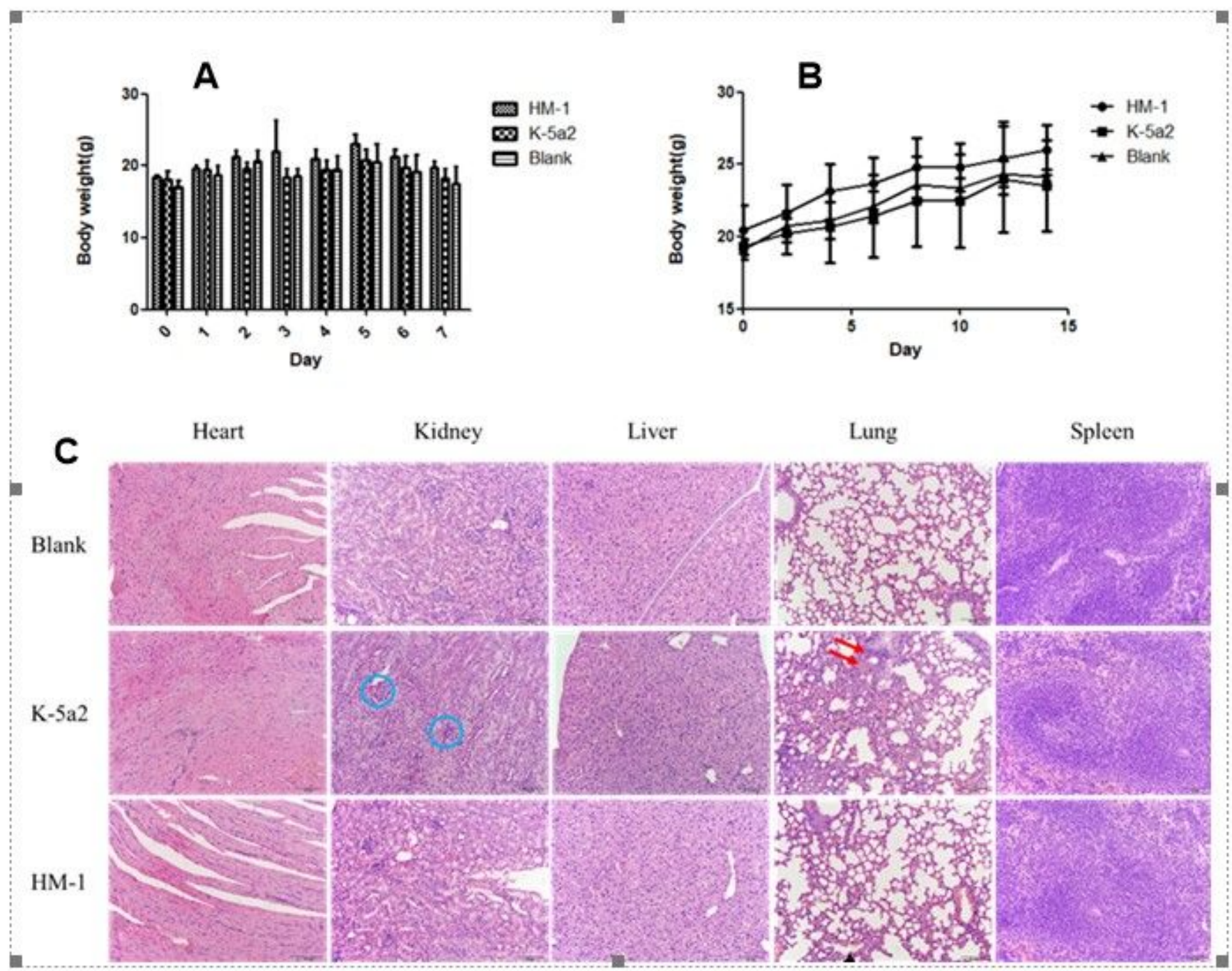

Figure 5. A. Body weight of all mice in three groups (g)-time (day) in acute toxicity experiment. B. Body weight of all mice in three groups (g)-time (day) in subacute toxicity experiment. C. HE of different organs of normal mice with K-5a2 $(60 \mathrm{mg} / \mathrm{kg})$ and HM-1 $(60 \mathrm{mg} / \mathrm{kg})$. Scale bars represent 50 um.

\section{Figure 5}

A. Body weight of all mice in three groups (g)-time (day) in acute toxicity experiment. B. Body weight of all mice in three groups (g)-time (day) in subacute toxicity experiment. C. HE of different organs of normal mice with K-5a2 $(60 \mathrm{mg} / \mathrm{kg})$ and HM-1 $(60 \mathrm{mg} / \mathrm{kg})$. Scale bars represent $50 \mu \mathrm{m}$. 
Scheme 1. Synthetic route of target compound HM-1.<smiles>CC#CC(=O)N1CCC(Nc2nc(Oc3c(C)cc(C#N)cc3C)c3sccc3n2)CC1</smiles><smiles>CCC(=O)NS(=O)(=O)c1ccc(CN2CCC(Nc3nc(Oc4c(C)cc(C#N)cc4C)c4sccc4n3)CC2)cc1</smiles>

K-5a2

HM-1

Reagents and conditions: (i) 3,5-dimethyl-4-hydroxybenzonitrile, DMF, $\mathrm{K}_{2} \mathrm{CO}_{3}$, rt; (ii) 4-(tertbutoxycarbonyl)aminopiperidine, DMF, $\mathrm{K}_{2} \mathrm{CO}_{3}, 120^{\circ} \mathrm{C}$; (iii) TFA, DCM, rt; (iv) 4bromomethylbenzenesulfonamide, $\mathrm{DMF}, \mathrm{K}_{2} \mathrm{CO}_{3}$, rt; (v) Propionic anhydride: Propionic acid = 1:4 (V/V), $120^{\circ} \mathrm{C}, 2 \mathrm{~h}$.

\section{Figure 6}

Scheme 1. Synthetic route of target compound HM-1.

\section{Supplementary Files}

This is a list of supplementary files associated with this preprint. Click to download.

- GraphicalAbstract.docx 